\title{
Anatomical Variations of Paranasal Sinuses Gender and Age Impact
}

\author{
Ibrahim Sumaily*, Saud Aldhabaan and Jibril Hudise \\ Otorhinolaryngologist, Asir Central Hospital, Saudi Arabia
}

Submission: February 21, 2018; Published: March 23, 2018

*Corresponding author: Ibrahim Sumaily, Otorhinolaryngologist, Asir Central Hospital, Saudi Arabia, Tel: +966504621902,

Email: sumaily.i@gmail.com

\begin{abstract}
Introduction: Anatomical variations are very important to be identified when planning a paranasal sinus (PNS) surgery. There is lack of studies among Saudi Arabia population in this entity to compare the findings among the main districts of the country. Herein we studied the incidence of different variations that should be evaluated preoperatively in the southern region of Saudi Arabia.

Method: A Cross-Sectional study. We reviewed the records of 420 adult patient who underwent computed tomography of PNS for different indications. We applied inclusion and exclusion criteria on them. The gender and age group variations evaluated and discussed. The findings compared to the literature. The data analysis done with SPSS v22.

Result: 293 met our inclusion criteria. The deviated nasal septum found in 30.7\%, Concha bullosa was present in $24.2 \%$, superior turbinate pneumatization in $1.7 \%$. Paradoxical middle turbinate in $9.5 \%$, crista gali pneumatization in $8.7 \%$, uncinate process attachment to lamina papyrecia in $73.7 \%$, frontal sinus was hyperpneumatized in $26.3 \%$, frontal air-cell in $25.9 \%$, supraorbital air-cell in $37.5 \%$, Onodi cell in $31.4 \%$, Haller cell in $25.9 \%$, sphenoid sinus hyperpneumatization in $24.2 \%$, anterior ethmoid artery running within the sinus cavity in $29.4 \%$, posterior ethmoid artery running within the sinus cavity in 5.5\%, type II depth of cribriform plate in $45.4 \%$, carotid artery dehiscence in $20.8 \%$, optic nerve was dehiscence in $15 \%$, sphenoid intersinus septum was attached to the carotid canal in $16.4 \%$, and to optic canal in $29.7 \%$.

Conclusion: The anatomical variations of nose and paranasal sinuses found to be different among regions and countries. We found differences in the neurovascular dehiscences, frontal sinus hyperpneumatization, supraorbital ethmoid air-cell, sphenoid sinus lateral pneumatization and age group differences. These are very important difference and should be evaluated carefully before starting a sinus surgery to avoid complications and incomplete surgery.
\end{abstract}

Keywords : Anatomical variation; Paranasal sinuses; Endoscopic surgery

\section{Introduction}

Anatomical variations are very important to be known, considered, and well identified in any surgical procedure, especially when planning fine surgeries. The endoscopic sinus surgery is one of those very fine surgeries. Knowing the different anatomical variations of the PNS is crucial for doing this surgery. As it is well known, there is a lot of racial variation among individuals. The English literature is rich in the description of anatomical variation of paranasal sinuses, but there is lack of such studies among Saudi Arabia population. Also, there is lack in studies tackling the age groups and gender differences in these variations. Herein we studied the incidence of different variations that can be evaluated radio logically and to be considered surgically, in the southern region of Saudi Arabia to specify any racial or age groups differences and emphasize on their clinical importance.

\section{Method}

A cross sectional study. We reviewed the records of 420 adult patients who underwent computed tomography (CT) for nose and paranasal sinuses for different indications between 2010-2015 in Asir Central Hospital. We included young adults to elderly Saudi patients, almost all from the southern provinces of Saudi Arabia, with CT cut thickness is 1 milli meter or less. We excluded Non-Saudi candidates, and those who have a disease, trauma or surgery that disturbed their normal anatomy. The candidate's gender and age considered. The age groups distributed according to A novel method for human age group classification based on Correlation Fractal Dimension of facial edges in which 15-30 years old is young adult, 31-50 years is middle-aged adults and 51 and more years old is senior adult [1-5]. The various clinically relevant anatomical variations 


\section{Global Journal of Otolaryngology}

assessed, correlated to the age groups and genders and the findings compared with the results of previous local, domestic, and international studies results. Those variations which are significantly different than what is recorded in the literature are highlighted. SPSS v.22 is used for data analysis.

\section{Result}

Out of 420 candidates, 293 met our criteria. 49.8\% males and $50.2 \%$ females. Ages ranged between 15 and 87 years with mean of 37.8, median 35 and standard deviation 14.6 years. Most of our candidates are young and middle-aged adults, $80.9 \%$. Deviated nasal septum found to be present in $30.7 \%$, mainly to right side (16\%). Among the age and gender groups it was highest in young adult female group (35.9\%). The concha bullosa seen in $24.2 \%$, of them $11.9 \%$ unilateral in the right

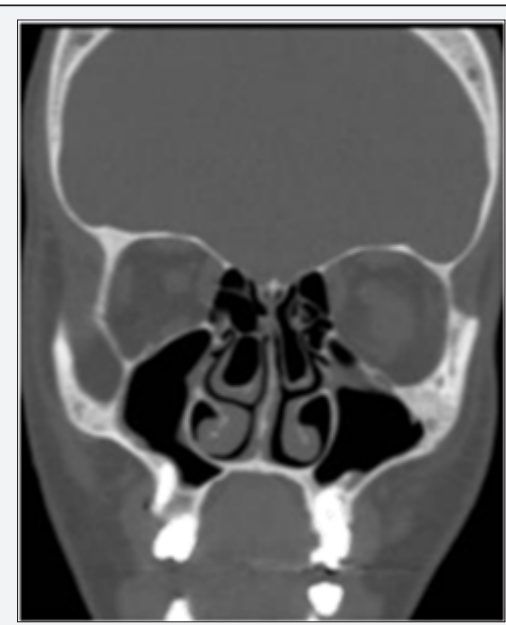

Figure 1: shows bilateral concha bullosa with pneumatization extending to the basal lamella.

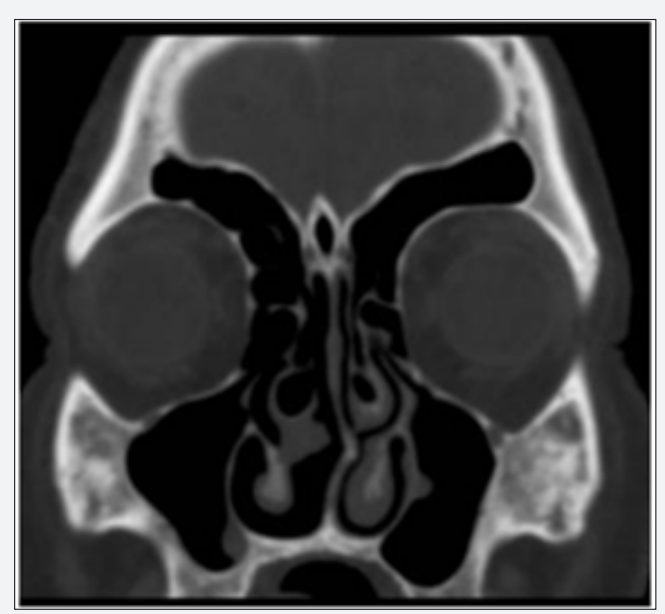

Figure 3 : shows Crista gali pneumatization associated with hyperpneumatized frontal sinus, supraorbital ethmoid air cells, bilateral concha bullosa with lamellar pneumatization and right paradoxical middle turbinate. side, $11.9 \%$ bilateral and 0.3 unilateral in the left side. It is less frequent in senior adults than the other age groups. Basal lamella pneumatization found in $3.1 \%$ (Figure 1). The superior turbinates were pneumatized in $1.7 \%$, all of them were having bilateral findings and $80 \%$ of them are males. Not seen in senior adults (Figure 2). The crista gali was pneumatized in $8.7 \%$, of them $69.6 \%$ are males [6,7]. Crista gali pneumatization was associated with hyperpneumatized frontal sinus. It was higher among senior adult age group, $14.3 \%$ (Figure 3). The middle turbinate found to be paradoxical in shape in $9.5 \%$, bilateral in $7 \%$. No gender or age group variations. No significant gender or age group variation (Figure 4). Uncinate process was attached to lamina papyrecia in $73.7 \%$, middle turbinate $17.4 \%(22.4 \%$ among females), skull base $8.9 \%$ (10.3\% among males). No significant age group variation (Figures $5 a$ \& 5b) [8]

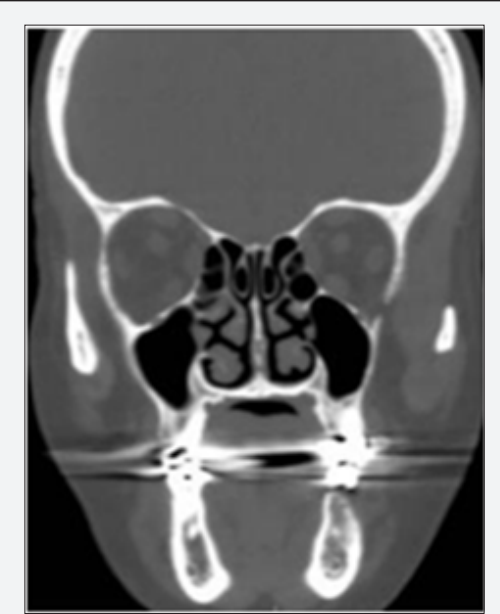

Figure 2 : shows bilateral superior turbinates pneumatisation.

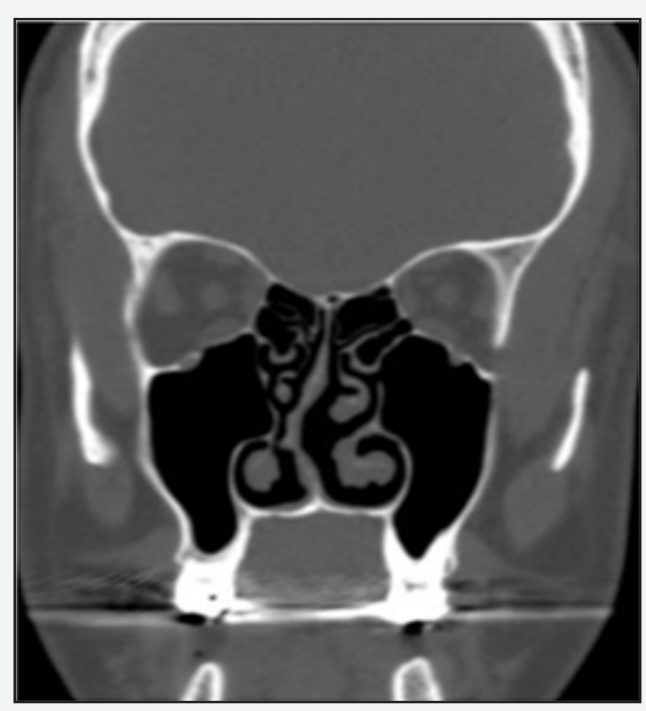

Figure 4 : shows bilateral paradoxical middle turbinates. 


\section{Global Journal of Otolaryngology}

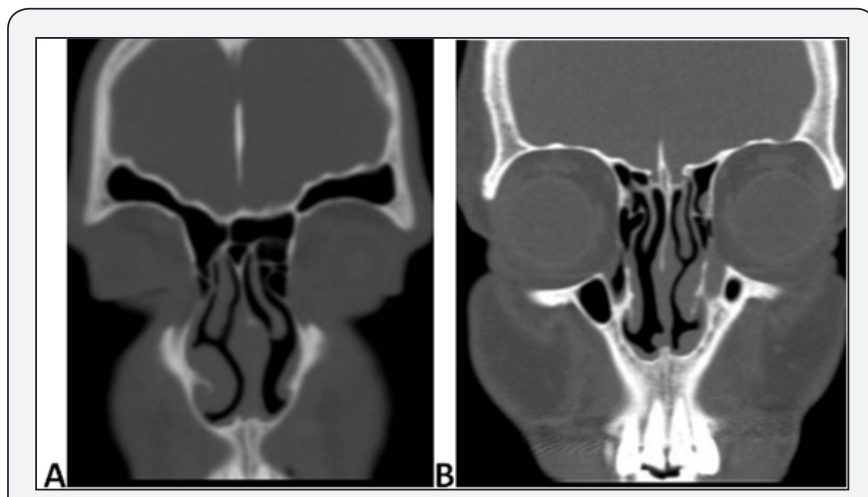

Figure 5 : shows the Uncinate process attached to the middle turbinate $(A)$ and skull base $(B)$.

The frontal sinus was hypoplostic in 10.2\% (15.6\% among females), and hyperpneumatized in $26.3 \%$ with higher incidence in males and middle-aged adult age group (35.6\% among males and 31.5 among middle age adults) (Figure 6). The frontal air-cell

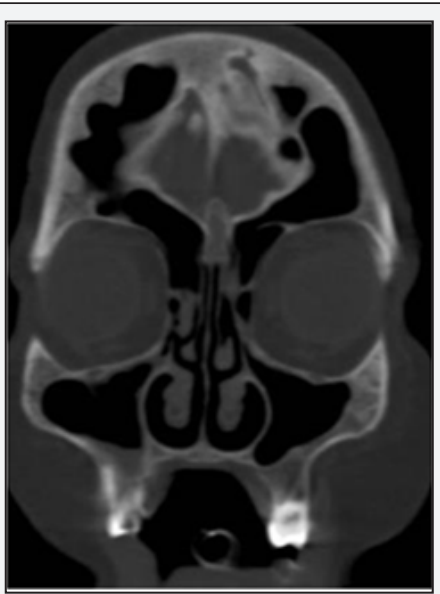

Figure 6 : shows hyperpneumatized frontal sinus.

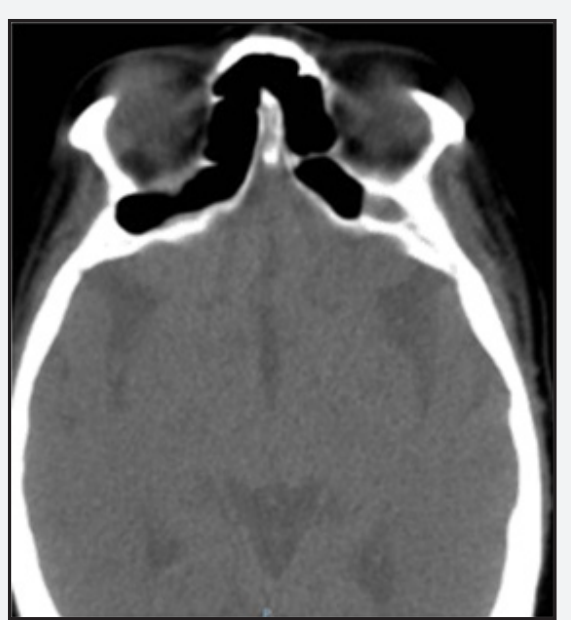

Figure 8 : shows bilateral supraorbital air-cell extending retroorbitally. found to be present in $25.9 \%$. Type I frontal air cell was the most prevalent (24\%) followed by type IV frontal air-cell (14\%, with higher incidence in senior adults, 23.2\%). No significant gender variations (Figure 7). The supraorbital air-cell was present in $37.5 \%$ (47.3\% among males and $27.4 \%$ among young adults and $51.8 \%$ among senior adults) (Figure 8). The Onodi air-cell, the most posterior posterior ethmoid air cell, found to be present in $31.4 \%$. No significant gender or age group variation (Figure 9). The Haller air-cell, the anterior ethmoid air cell that lies in the orbital floor, found to be present in $25.9 \%$. No significant gender or age group variation (Figure 10). The sphenoid sinus lateral pneumatization in $24.2 \%$ [9-12]. While the conchal type in $1 \%$ only. The sinus is relatively smaller in senior adult age group. No significant gender variation (Figure 11). The anterior ethmoid artery was protected with bony canal within the roof in $37.5 \%$, superficial on the sealing in $33.1 \%$, and within the sinus cavity with very thin or no bony protection in $29.4 \%$. In senior adult age group, $44.6 \%$ has the artery running within the sinus cavity [13]. No significant gender variation (Figure 12).
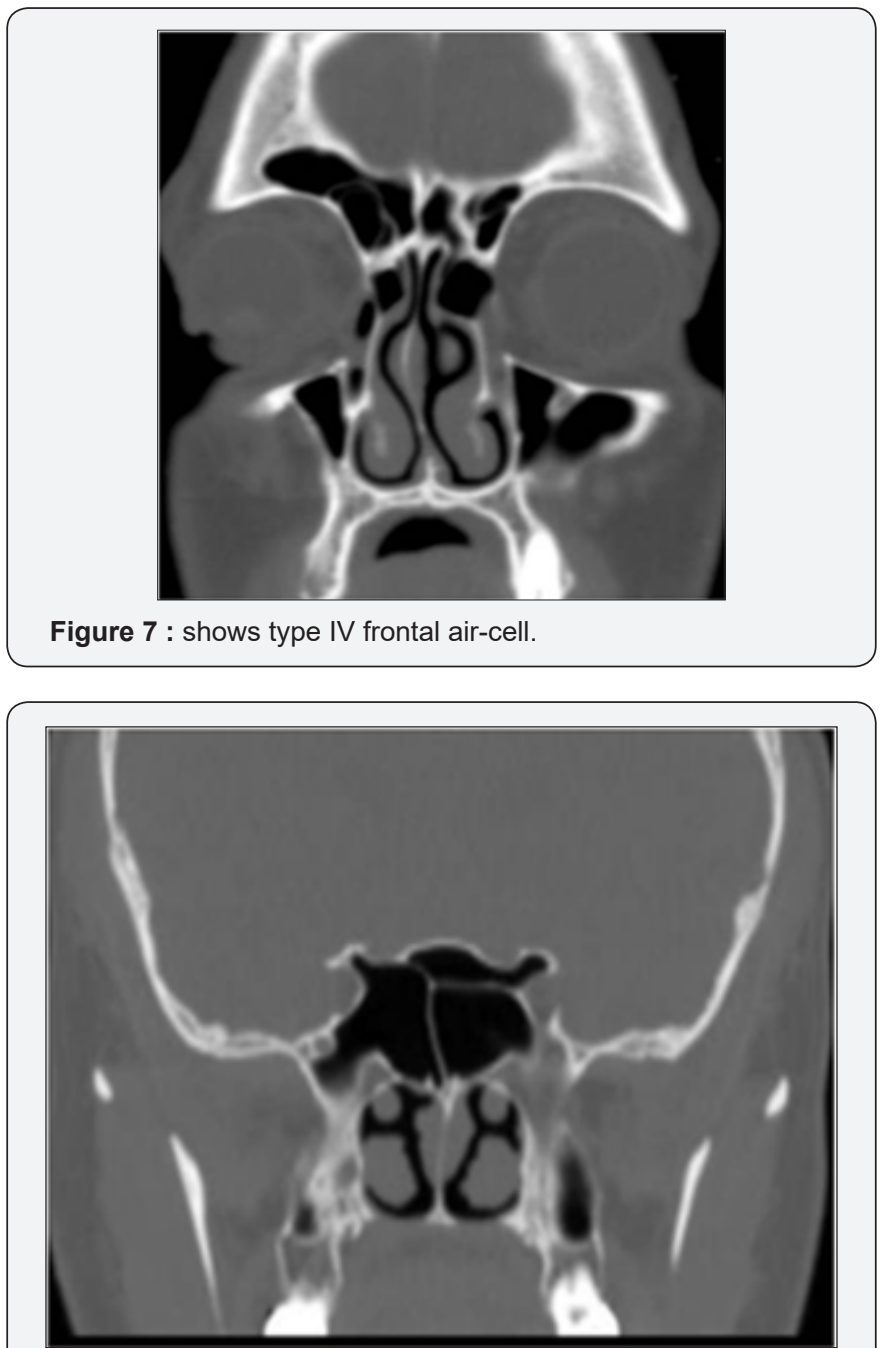

Figure 9 : Shows left Onodi air-cell. 


\section{Global Journal of Otolaryngology}

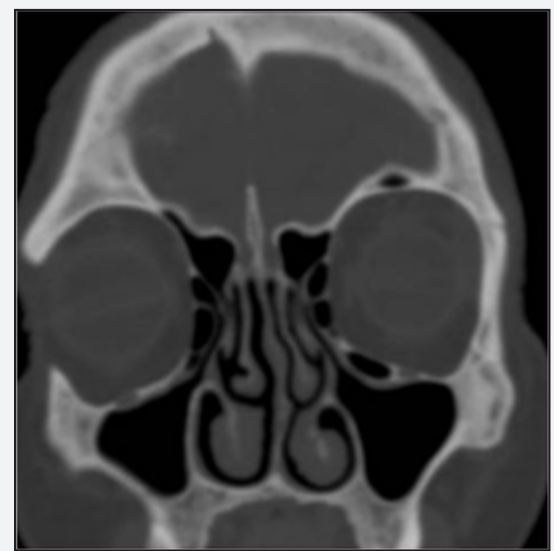

Figure 10 : Shows Haller air-cell.

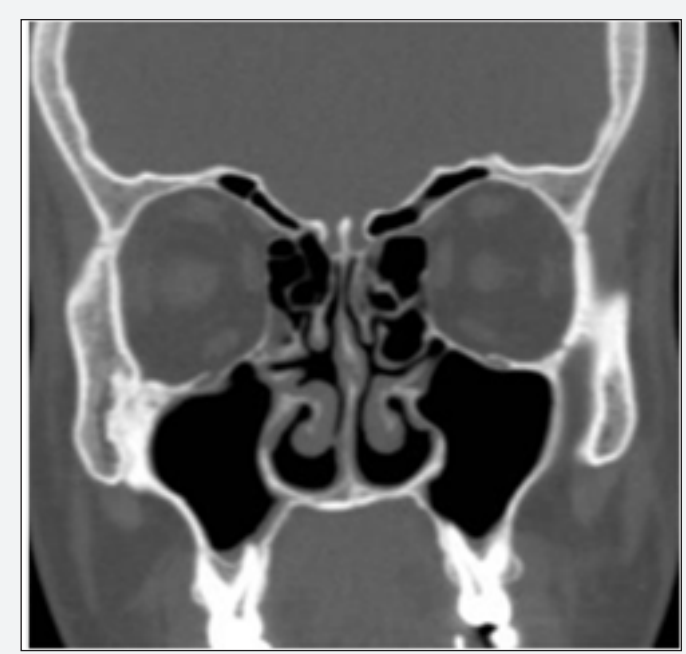

Figure 12 : Shows the anterior ethmoid arteries passing within the anterior ethmoid air-cells.

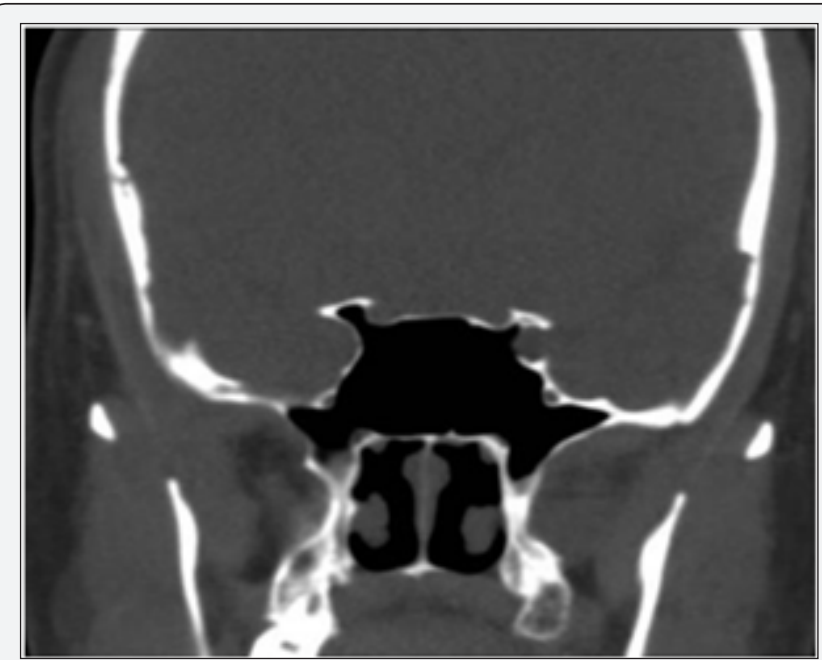

Figure 14 : Shows the carotid artery projecting partially into the sphenoid sinus cavity without bony partition.

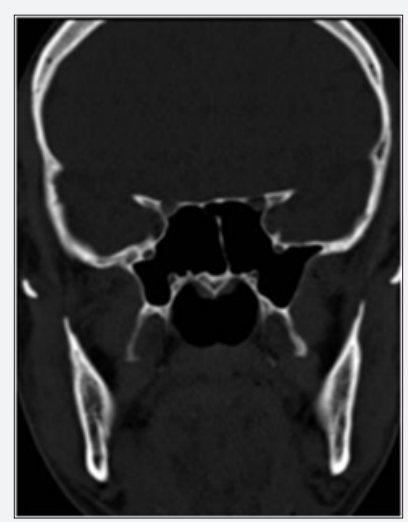

Figure 11 : Shows bilateral hyperpneumatized sphenoid sinuses.

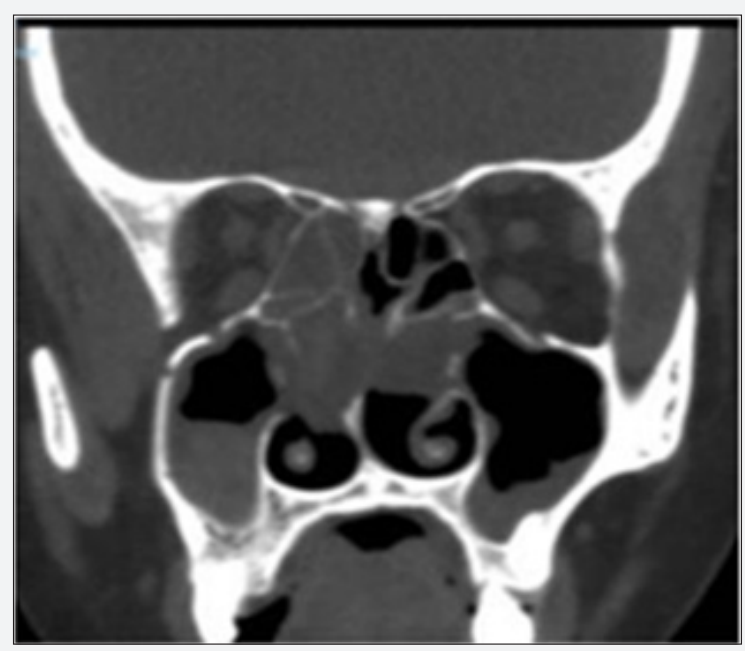

Figure 13 : Shows the posterior ethmoid artery passing within the posterior ethmoid air-cells.

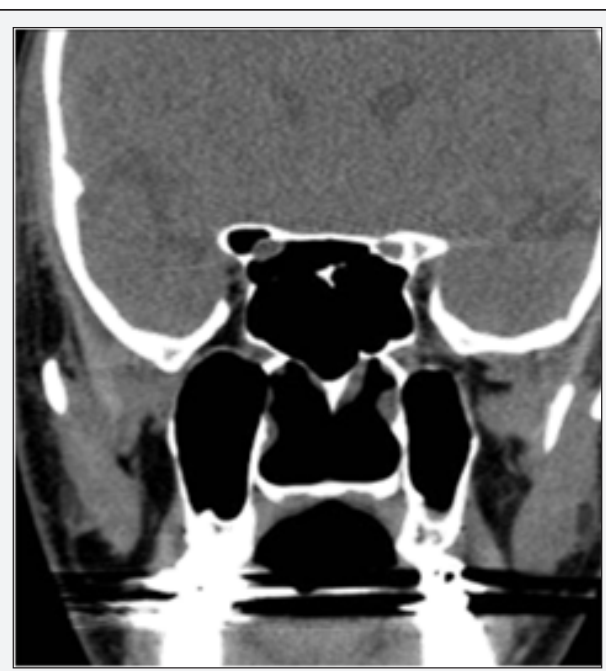

Figure 15 : Shows the optic nerve passing within the sphenoid sinus without bony partition. 


\section{Global Journal of Otolaryngology}

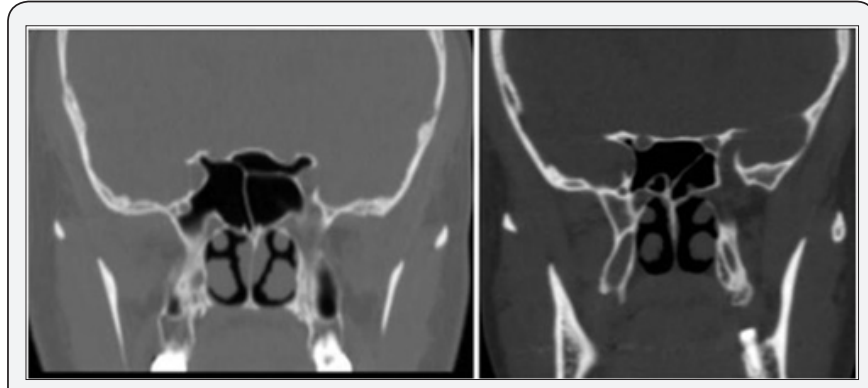

Figure 16 : shows the sphenoid sinus septum attached to the optic nerve (a) and the bony partition between Onodi cell and the sphenoid sinus attached to the carotid artery.

The posterior ethmoid artery was protected with bony canal within the roof in $66.9 \%$ and superficial on the sealing in 27.6 within the sinus cavity with or without bony protection in $5.5 \%$ (6.8\% among males). In senior adult age group, $10.7 \%$ has the artery running within the sinus cavity (Figure 13). The depth of cribriform plate (Keros classification) was type II in $45.4 \%$, type I in $33.4 \%$, type III in $12.6 \%$ and asymmetrical in $8.5 \%$. No significant gender or age group variation [14]. The carotid artery was dehiscent in $20.8 \%$, the artery was bulging into the sinus cavity in $6.8 \%$. No significant gender or age group variation (Figure 14). Optic nerve was dehiscent in 15\%, of them $6.7 \%$ the nerve was bulging into the sinus cavity. No significant gender variation. The incidence of bulging nerve into the sinus cavity is less frequent in the senior adult age group (3.6\%) (Figure 15). The sphenoid intersinus septum was attached to the carotid canal in $16.4 \%$, and to optic canal in $29.7 \%$. Among the senior adult age group, it is attached to the carotid canal in $26.8 \%$. No significant gender variation (Figure 16a \& 16b).

\section{Discussion}

Sino nasal anatomy is very complex clinically and radio logically. What makes it more complex is the wide variety of anatomical variations that may influences the path physiology and the surgical procedures in this area [15]. Therefore, it needs to be well understood by the surgeon. Endoscopic sinus surgery is a fine procedure, in which the surgeon should be meticulous and well oriented about each part of this complex anatomy. The English literature is rich in the description of anatomical variation of paranasal sinuses, but there is lack of such studies among Saudi Arabia population. Studying and reporting these variations in our society should be helpful for otorhinolaryngologist to consider those variations while dealing with their patients in our region and for planning the surgical interventions on them. In the human being, 4 pairs of paranasal sinus are there. Embryo logically developing in this sequence, ethmoid, maxillary, sphenoid, and frontal. These sinuses have different extent of development and pneumatization, and variable relations with the surrounding structures, especially orbit and skull base. Also the lateral nasal wall composed of three turbinate's, uncinate process and perpendicular plate of palatine bone. Each of these structures has variant relations with sinuses, orbit and skull base $[16,17]$.

The imaging investigation, CT as a gold standard, for the anatomical variation of the paranasal sinuses is very important these variations and in correlating them with the inflammatory changes of the paranasal sinuses. Also it is very important for planning any surgical intervention. Inadvertent violation of the cribriform plate may cause CSF leak, direct penetration trauma to the dura, serious intracranial and intracerebral complications [2,3]. In the regional and domestic literature, three studies published tackling these variations. One of them in eastern province of Saudi Arabia evaluated 121 candidates for these variations and concluded that there is a difference in the prevalence of some variants among Saudi population compared with other study groups [4]. Another domestic study conducted in Oman and concluded that type 3 olfactory fossa (low lying cribriform plate) is present in more than the third of the Omani population. This is in contrast to the Caucasian and Indian populations where type 1 and type 2 are more common, respectively [5]. Nouarei et al. studied 278 patients in 2009 for the incidence of anatomical variations and concluded that there is no relationship between anatomic variations of the bony structures and the risk to develop mucosal disease of the sinus but they cannot exclude the potential impact on the safety of the surgery. Therefore, these anatomic variations need to be assessed in the preoperative evaluation [6] (Table 1).

Table 1: Showing the various anatomical variation that we reported in our research and comparison of the most recent and relevant local, domestic and international studies.z

\begin{tabular}{|c|c|c|c|c|c|c|c|c|c|c|c|c|c|c|c|c|}
\hline $\begin{array}{c}\text { Study } \\
\text { Anatomical } \\
\text { Variation \% }\end{array}$ & $\begin{array}{c}\text { Perez- } \\
\text { Pinas } \\
\text { et al. } \\
\text { [7] }\end{array}$ & $\begin{array}{c}\text { Badia } \\
\text { et al. } \\
\text { [8] }\end{array}$ & $\begin{array}{c}\text { Badia } \\
\text { et al. } \\
\text { [8] }\end{array}$ & $\begin{array}{c}\text { Lerdlum } \\
\& \\
\text { Vachira- } \\
\text { nubhap } \\
\text { [9] }\end{array}$ & $\begin{array}{l}\text { Dua } \\
\text { et al. } \\
{[10]}\end{array}$ & $\begin{array}{c}\text { Caughey } \\
\text { et al. } \\
\text { [11] }\end{array}$ & $\begin{array}{l}\text { Mazza } \\
\text { et al. } \\
\text { [12] }\end{array}$ & $\begin{array}{c}\text { Nouraei } \\
\text { et al. } \\
\text { [6] }\end{array}$ & $\begin{array}{c}\text { Al- } \\
\text { Qudah } \\
{[13]}\end{array}$ & $\begin{array}{c}\text { Mamatha } \\
\text { et al. } \\
\text { [14] }\end{array}$ & $\begin{array}{c}\text { Fadda } \\
\text { et al. } \\
\text { [15] }\end{array}$ & $\begin{array}{l}\text { Adeel } \\
\text { et al. } \\
{[16]}\end{array}$ & $\begin{array}{c}\text { Al-Abri } \\
\text { et al. } \\
\text { [5] }\end{array}$ & $\begin{array}{c}\text { Roman } \\
\text { et al. } \\
\text { [17] }\end{array}$ & $\begin{array}{c}\text { Alrumaih } \\
\text { et al. } \\
\text { [4] }\end{array}$ & $\begin{array}{c}\text { Sumaily } \\
\text { et al } \\
\text { [urrent } \\
\text { study] }\end{array}$ \\
\hline Year & 2000 & 2005 & 2005 & 2005 & 2005 & 2005 & 2007 & 2009 & 2010 & 2010 & 2012 & 2013 & 2014 & 2015 & 2016 & 2017 \\
\hline Country & Spain & $\begin{array}{l}\text { Hong } \\
\text { Kong }\end{array}$ & $\begin{array}{c}\text { United } \\
\text { King- } \\
\text { dom }\end{array}$ & Thailand & India & USA & Italy & $\begin{array}{c}\text { United } \\
\text { Kingdom }\end{array}$ & Jordon & India & Italy & Pakistan & Oman & Romania & $\begin{array}{c}\text { Saudi } \\
\text { Arabia }\end{array}$ & $\begin{array}{l}\text { Saudi } \\
\text { Arabia }\end{array}$ \\
\hline $\begin{array}{l}\text { Number of } \\
\text { candidates }\end{array}$ & 110 & 100 & 100 & 133 & 50 & 250 & 100 & 278 & 110 & 40 & 200 & 77 & 360 & 130 & 121 & 293 \\
\hline
\end{tabular}




\begin{tabular}{|c|c|c|c|c|c|c|c|c|c|c|c|c|c|c|c|c|}
\hline DNS & 58 & 15 & 33 & 56.4 & 44 & - & - & - & 43 & 65 & 82 & 26 & 80 & - & - & 30.7 \\
\hline $\begin{array}{l}\text { concha } \\
\text { bullosa }\end{array}$ & 24.5 & 9.5 & 31 & 14.3 & 16 & 27.4 & 29 & 35.4 & 62 & 15 & 2.8 & 18.2 & 49 & 35.3 & 55.4 & 24.2 \\
\hline $\begin{array}{c}\text { Basal lamella } \\
\text { pneumatization }\end{array}$ & 15.7 & - & - & - & - & - & - & - & - & - & - & - & - & - & - & 3.1 \\
\hline $\begin{array}{c}\text { superior } \\
\text { turbinates } \\
\text { pneumatization }\end{array}$ & - & - & - & - & - & - & - & - & 25 & - & - & - & 1.4 & - & - & 1.7 \\
\hline $\begin{array}{c}\text { crista gali } \\
\text { pneumatization }\end{array}$ & - & - & - & - & - & - & - & - & 28 & - & 13.6 & - & 0.3 & - & 89.2 & 8.7 \\
\hline $\begin{array}{l}\text { Paradoxical } \\
\text { middle } \\
\text { turbinate }\end{array}$ & 5 & 6.5 & 22 & 5.3 & 10 & - & 11 & 0.7 & 18 & - & 6.4 & 14.3 & 13 & 8 & 12.4 & 9.5 \\
\hline $\begin{array}{l}\text { Uncinate } \\
\text { process } \\
\text { attachment }\end{array}$ & - & - & - & - & - & - & - & - & - & LP 40 & - & - & - & SB 46 & - & LP 73.7 \\
\hline $\begin{array}{c}\text { Frontal sinus } \\
\text { hyperpneu_ } \\
\text { matization }\end{array}$ & - & - & - & - & - & - & - & - & - & - & 2.1 & - & - & - & - & 26.3 \\
\hline $\begin{array}{l}\text { Frontal } \\
\text { air cell }\end{array}$ & - & - & - & - & - & - & - & - & - & - & Type I & - & - & - & Type I & Type I \\
\hline $\begin{array}{l}\text { supraorbital } \\
\text { air-cell }\end{array}$ & & 2 & 17 & - & - & - & - & 6.1 & - & - & - & - & 13 & - & - & 37.5 \\
\hline Onodi cell & 10.9 & 33 & 17 & - & 3 & - & 9 & 4.7 & - & - & 8.5 & 6 & 7.5 & 8 & 35 & 31.4 \\
\hline Hallar cell & 45 & 5 & 15 & 9.4 & 16 & 27 & 5 & 12.2 & 20 & 17.5 & 22.8 & 9.1 & 24 & 25 & 39.7 & 25.9 \\
\hline $\begin{array}{c}\text { Sphenoid } \\
\text { lateral } \\
\text { pneumatization }\end{array}$ & - & 12 & 6 & - & - & - & - & 11 & - & - & - & - & - & - & - & 24.2 \\
\hline $\begin{array}{c}\text { Anterior } \\
\text { ethmoid } \\
\text { artery }\end{array}$ & - & - & - & - & - & - & - & - & - & - & - & - & $\begin{array}{c}\text { Bony } \\
\text { canal } \\
14\end{array}$ & - & - & $\begin{array}{c}\text { In the } \\
\text { sinus } \\
29.4\end{array}$ \\
\hline $\begin{array}{l}\text { Posterior } \\
\text { ethmoid } \\
\text { artery }\end{array}$ & - & - & - & - & - & - & - & - & - & - & - & - & - & - & - & $\begin{array}{c}\text { In the roof } \\
66.9\end{array}$ \\
\hline $\begin{array}{c}\text { Keros } \\
\text { classification }\end{array}$ & - & $\begin{array}{c}\text { Type I } \\
29\end{array}$ & $\begin{array}{l}\text { Type I } \\
27\end{array}$ & - & - & - & - & Type I 92 & - & - & Type I & - & $\begin{array}{c}\text { Type } 3 \\
36\end{array}$ & Type IV & $\begin{array}{c}\text { Type II } \\
52.9\end{array}$ & $\begin{array}{l}\text { Type II } \\
45.4\end{array}$ \\
\hline $\begin{array}{l}\text { Carotid artery } \\
\text { dehiscence }\end{array}$ & - & 0 & 3 & - & - & - & - & - & - & - & - & - & - & - & 1.7 & 20.8 \\
\hline $\begin{array}{l}\text { Optic nerve } \\
\text { dehiscence }\end{array}$ & - & 0 & 2 & - & - & - & - & - & - & - & - & - & 0.8 & - & - & 15 \\
\hline $\begin{array}{l}\text { Sphenoid } \\
\text { septum } \\
\text { direction }\end{array}$ & - & $\begin{array}{c}\text { Carotid } \\
35\end{array}$ & $\begin{array}{c}\text { Carotid } \\
36\end{array}$ & - & - & - & - & - & - & - & - & - & $\begin{array}{c}\text { Carotid } \\
0.8\end{array}$ & - & - & Optic 29.7 \\
\hline
\end{tabular}

In the literature, up to our knowledge, no study assessed the gender and age group relation to these anatomical variations in details. In our study there is lower incidence of deviated nasal septum in comparison to other studies. This can be explained by the inclusion criteria which mandate a thin cut CT scan. This study is not used to assess the incidence of deviated nasal septum. May be for the same reason, in the literature some studies have nearly same incidence $[8,16]$.

The incidence of concha bullosa is almost the half of what mentioned in the local and domestic studies. But in comparison to the overall reviewed papers it is around the mean. The middle turbinate lamellar pneumatization is not mentioned in most of the reviewed papers. Among the recent studies only one study reported it is incidence which is five time the incidence we found in our candidates. Superior turbinate pneumatization is not studied well also. In the recent studies, only two studies reported its incidence with great difference between the findings although both are domestic studies $[5,13]$. In our study its nearly the same as the finding in Oman study [5].

Crita gali pneumatization is mentioned in four studies in the literature $[4,5,13,15]$. Our finding is much less than the finding of Alrumaih et al which was conducted in the eastern region of our country. The other three studies reported variable incidences. The paradoxical middle turbinate was tackled in many studies with no much variable findings. 
In our studies its found to be around the average of other studies findings. The uncinate process attachment is not clearly mentioned in most of the studies. Two studies reported the higher incidence of attachment type of uncinate process $[14,17]$. In our studies the incidence of attachment to lamina papyrecia is higher than what is reported in the other studies. This type of uncinate process is associated with drainage of frontal sinus into the middle meatus directly, which is theoretically associated with better drainage of frontal sinus.

Among the recent studies on various anatomical variations of paranasal sinuses, the frontal sinus hyperpneumatization is mention in one study only [15]. In our study, there is much higher incidence of frontal sinus hyperpneumatization extending to the level of the mid-globe and even beyond. The frontal air-cell found to have same predominance of type I. But we found a higher incidence of type IV cells in our candidates. The supraorbital air-cell is reported in three studies $[6,5,8]$. In our sample, there is much higher incidence of this type of anterior ethmoid air-cells. This is very important to be evaluated as hidden disease can be missed there leading to persistence or recurrence of the symptoms.

The Hallar and Onodi ethmoid air-cells are well studied in the recent papers. In our study the Hallar air-cell is about the average of the findings of the other studies. While the Onodi air-cell found to be higher than most of the other studies, except two studies showed even higher incidence of this variation, one was conducted in the Eastern Region of Saudi Arabi and the other in Hong Kong [4,8]. The lateral pneumatization of sphenoid sinus is two studies $[6,8]$. One of them actually mentioned the clinoid process pneumatization which showed a lower incidence than our sample. The other one reported the incidence of sphenoid sinus pneumatization laterally where the incidence was also lower than our sample findings.

The position and dehiscence of anterior and posterior ethmoid artery is not well studied in the papers tackled the various anatomical variations. In our sample we found it running within the anterior ethmoid air-cells in about the third. Most of them with thin or no bony canal. While the posterior ethmoid artery is almost always protected with bony canal. But in minority of cases it was running within the sinus cavity. The depth of the cribriform plate of ethmoid, the Keros classification in our sample is comparable to most of the other studies where type II is the most predominant type.

Among the reviewed papers, the internal carotid artery canal dehiscence is mentioned in two studies only $[4,8]$. The incidence of dehiscence is significantly higher in our candidates. The optic nerve canal dehiscence also found to be much more in our candidates in comparison to the other two studies reported it $[5,8]$. There is very important to take care of while reviewing and planning endoscopic sinus surgery in our region. While the sphenoid intersinus septum found to be mainly centrally positioned with lower incidence of attachment to internal carotid artery canal, but higher incidence of attachment to the optic canal.

\section{Conclusion}

The anatomical variation of nose and paranasal sinuses is very important to be identified preoperatively. These variations found to be different among regions and countries. In our study, we found differences in very risky parts from what is mentioned in other studies, in

\section{References}

1. Yarlagadda Anuradha, Murthy J V R, Prasad MHM, Krishna A (2015) Novel method for human age group classification based on correlation fractal dimension of facial edges. Journal of King Saud University-Computer and Information Sciences 27 (4): 468-476.

2. Lebowitz RA, Terk A, Jacobs JB, Holliday RA (2001) Asymmetry of the ethmoid roof: analysis using coronal computed tomography. Laryngoscope 111(12): 2122-2124.

3. Başak S, Akdilli A, Karaman CZ, Kunt T (2000) Assessment of some important anatomical variations and dangerous areas of the paranasal sinuses by computed tomography in children. Int J Pediatr Otorhinolaryngol 55(2): 81-89.

4. Alrumaih RA, Mona M Ashoor, Ahmed A Ob (2016) Radiological sinonasal anatomy. Exploring the Saudi population. Saudi Med J 37: 521-526.

5. Al Abri R, Bhargava D, Al-Bassam W, Al Badaai Y, Sawhney S (2014) Clinically significant anatomical variants of the paranasal sinuses. Oman Med J 29(2): 110-113.

6. Nouraei SA, Elisay AR, Dimarco A, Abdi R, Majidi H, et al. (2009) Variations in paranasal sinus anatomy: implications for the pathophysiology of chronic rhinosinusitis and safety of endoscopic sinus surgery. J Otolaryngol Head Neck Surg 38(1): 32-37.

7. Perez Pinas I, Sabate J, Carmona A, Catalina-Herrera CJ, Jimenez Castellanos J (2000) Anatomical variations in the human paranasal sinus region studied by CT. The Journal of Anatomy 197(2): 221227.

8. Badia L, Lund VJ, Wei W, Ho WK (2005) Ethnic variation in sinonasal anatomy on CT-scanning. Rhinology 43(3): 210.

9. Lerdlum S, Vachiranubhap B (2005) Prevalence of anatomic variation demonstrated on screening sinus computed tomography and clinical correlation. Journal of the Medical Association of Thailand Chotmaihet thangphaet 88: S110-S115.

10. Dua K, Chopra H, Khurana AS, Munjal M (2005) CT scan variations in chronic sinusitis. Indian Journal of Radiology and Imaging 15(3): 315.

11. Caughey RJ, Jameson MJ, Gross CW, Han JK (2005) Anatomic risk factors for sinus disease: fact or fiction? American journal of rhinology 19(4): 334-339.

12. Adeel M, Rajput MS, Akhter S, Ikram M, Arain A, et al. (2013) Anatomical variations of nose and para-nasal sinuses; CT scan review. Journal of the Pakistan Medical Association 63(3): 317.

13. Al-Qudah MA (2010) Anatomical variations in sinonasal region: A computer tomography (CT) study. J Med J 44(3): 290-297. 
14. Mamatha H, Shamasundar NM, Bharathi MB, Prasanna LC (2010) Variations of ostiomeatal complex and its applied anatomy: a CT scan study. Indian journal of science and technology 3(8): 904-907.

15. Fadda GL, Rosso S, Aversa S, Petrelli A, Ondolo C, et al. (2012) Multiparametric statistical correlations between paranasal sinus anatomic variations and chronic rhinosinusitis. Acta Otorhinolaryngologica Italica 32(4): 244-251.
16. Adeel M, Rajput MS, Akhter S, Ikram M, Arain A, et al. (2013) Anatomical variations of nose and para nasal sinuses; CT scan review. Journal of the Pakistan Medical Association 63(3): 317.

17. Roman RA, Hedeşiu M, Gersak M, Fidan F, Băciuţ G, Băciuţ M (2016) Assessing the prevalence of paranasal sinuses anatomical variants in patients with sinusitis using Cone Beam Computer Tomography. Clujul Medical 89(3): 423.

\section{Your next submission with Juniper Publishers will reach you the below assets}

- Quality Editorial service

- Swift Peer Review

- Reprints availability

- E-prints Service

- Manuscript Podcast for convenient understanding

- Global attainment for your research

- Manuscript accessibility in different formats ( Pdf, E-pub, Full Text, Audio)

- Unceasing customer service

Track the below URL for one-step submission https://juniperpublishers.com/online-submission.php 